\title{
脳静脈洞血栓症
}

新堂晃大 ${ }^{1 *}$ ，和田英夫 ${ }^{2}$, 冨本秀和 ${ }^{1}$

\section{Cerebral venous thrombosis}

Akihiro SHINDO $^{1}$, Hideo WADA ${ }^{2}$, and Hidekazu TомIMOTO ${ }^{1}$

Key words: 脳卒中, 若年性脳梗塞, 血栓性素因

\section{1.はじめに}

脳静脈洞血栓症は全脳卒中の約 $0.5 \sim 1 \%$ と比較的 まれな頻度で発症し，若年者からみられる疾患であ る ${ }^{1)}$ 。症状の多様性や多彩な病態が関与することか ら診断が困難な症例も存在するが，近年，画像診断 の発達などにより多くの知見が得られるようになっ た。多彩な臨床像は原因と症状の両者が関連し，原 因には遺伝性素因(血栓性素因) と後天性素因が存在 すること，また症状においては，頭蓋内圧立進症状 と局所脳症状が混在し, 局所脳症状では動脈の血管 支配に一致しない所見があることから脳静脈洞血栓 症の診断が困難なときが存在する.

本稿では，脳静脈洞血栓症の危険因子，診断と治 療について述べる。

\section{2. 疫学と危険因子}

先にも述べたとおり，脳静脈洞血栓症は全脳卒中 の $0.5 \sim 1 \%$ と比較的まれな脳卒中である。 とくに若 年層に認めることが多いとされており， International Study of Cerebral Venous and Dural Sinuses Thrombosis(ISCVT)では約 78\%が 50 歳未満で発症すると

${ }^{1}$ 三重大学医学部医学系研究科神経病態内科学

2 三重大学医学部医学系研究科検査医学

*責任者連絡先：

三重大学医学部医学系研究科神経病態内科学

干 514-8507 三重県津市江戸橋 2-174

Tel: 059-231-5107, Fax: 059-231-5082

E-mail: a-shindo@clin.medic.mie-u.ac.jp
報告されている2).

脳静脈洞血栓症の誘発因子は多彩である。その危 険因子には, Virchow の 3 徵が静脈血栓症の誘発因 子として提唱した, (1)血流の停滞, (2)静脈壁の障害, (3)血液凝固能の克進が種々に絡み合う。危険因子は 通常，遺伝性因子の血栓性素因と手術や悪性腫瘍な どの後天性因子とに分けることができる。

\section{1）遺伝性血栓性素因}

American Heart Association (AHA)/American Stroke Association (ASA) の脳静脈洞血栓症ガイドライン ${ }^{3)}$ では，血栓性素因としてアンチスロンビン III，プ ロテイン $\mathrm{C}$ とプロテイン $\mathrm{S}$ 欠乏症が，また遺伝性 素因としては Factor V Leiden 遺伝子異常症と Prothrombin G20210A 変異を挙げている。欧米での報 告では，静脈血栓症のリスクに，Factor V Leiden と Prothrombin G20210A の遺伝子異常が多く挙げられ， 脳静脈洞血栓症でもその傾向がある ${ }^{4)}$. Bombeli ら の報告では，脳静脈洞血栓症における先天性血栓性 素因は全体の $23.5 \%$ とされ，そのほとんどが上記遺 伝子変異であった ${ }^{4)}$ ，筆者らは本邦における脳静脈 洞血栓症の遺伝性素因について検討し, 22 例中 7 例(約 32\%) に遺伝子異常を認めたことを報告した $(\text { 表 1 })^{5)}$ ，その内訳は，プロテイン $\mathrm{S}$ 遺伝子異常症 が 4 例，プロテイン $\mathrm{C}$ 遺伝子異常症が 2 例であり，

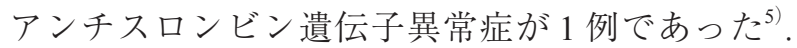
つまり欧米と比較し，背景に遺伝性血栓性素因を認 める傾向が強い傾向があり，また遺伝子異常症の内 容も異なることが判明した。これは日本人の静脈血 栓では, Factor V Leiden 遺伝子異常と Prothrombin G20210A 遺伝子異常を認めず，プロテイン $\mathrm{S}$ 欠損 
表 1 本邦における脳静脈洞血栓症の原因（文献５より）

\begin{tabular}{ccc}
\hline \multicolumn{1}{c}{ 原因 } & 例数 & $\%$ \\
\hline 先天性血栓性素因 & 全 7 例 & 31.8 \\
Protein S 遺伝子異常症 & 4 例 & 18.2 \\
Protein C 遺伝子異常症 & 2 例 & 9.1 \\
ATIII 遺伝子異常症 & 1 例 & 4.5 \\
後天性血栓性素因 & 全 6 例 & 27.3 \\
Protein S 欠乏症 & 2 例 & 9.1 \\
Protein C 欠乏症 & 1 例 & 4.5 \\
ATIII 欠乏症 & 1 例 & 4.5 \\
抗リン脂質抗体症候群 & 2 例 & 9.1 \\
その他 & 全 6 例 & 27.3 \\
鉄欠乏性貧血 & 3 例 & 13.6 \\
骨䯣異形成症候群 & 1 例 \\
高度脱水 & 1 例 & 4.5 \\
多臓器不全 & 1 例 & 4.5 \\
原因不明 & 全 3 例 & 4.5 \\
\hline
\end{tabular}

症の関与が強いとする既報告と一致する ${ }^{6,7)}$.

\section{2）後天性血栓性素因}

先にも述べたように，外科手術や外傷，妊娠など が関与する。 そのほか, 抗リン脂質抗体症候群や外 傷が挙げられる ${ }^{3)}$. 鉄欠乏性貧血 ${ }^{8)}$, 発作性夜間血. 色素尿症 ${ }^{9}$, 炎症性腸症候群 ${ }^{10,11)}$ やベーチェット 病 ${ }^{12)}$ も原因として報告されている。とくに妊娠およ び産裖期は血栓形成をしやすい状況にあるため注意 が必要である。赤澤らの報告 ${ }^{13)} て ゙ は ，$ 妊娠に伴う脳 静脈洞血栓症で, 妊娠初期と産裖期に発症する症例 が多く，母体死亡例も認めるため注意が必要である としている。 また経口避妊薬の服用も血栓症のリス クとなるため注意が必要である.

\section{3. 診断}

\section{1）臨床所見}

脳静脈洞血栓症の臨床所見は, 頭蓋内圧光進と局 所の脳障害に伴う症状からなり, 多くの場合は両者 が共存する。頭蓋内圧光進症状では, 頭痛が最も多 く認められる症状で約 $90 \%$ に存在する ${ }^{10)}$. 頭痛は 数日から数週間持続することもあり，急性頭痛のみ でなく亜急性症状としても注意が必要である。また 雷鳴頭痛や片頭痛様の症状を呈する症例も存在す る ${ }^{14)}$. 頭蓋内圧方進症状として, そのほかに乳頭浮
腫や複視も出現する。頭痛と乳頭浮腫や複視を呈す る症例では，脳静脈洞血栓症が重要な鑑別診断とな る。局所脳障害は, 静脈血栓や出血に伴い生じ, 片 麻痺や失語, 感覚障害, 精神症状も出現する。痤攣 発作は約 $40 \%$ に生じるとされ，注意が必要である。

\section{2）検查所見}

血液検査では, 血算, 生化学, 凝固の評価が必須 である。深部静脈血栓や肺血栓症の診断で有用とさ れる D-dimer も脳静脈洞血栓症の診断において重要 と報告されている ${ }^{15)}$.

画像診断は頭部単純 CT, 造影 CT, CT venography $(\mathrm{CTV})$, 頭部単純 MRI や MR venography (MRV), 脳血管撮影などが挙げられる。頭部単純 CT では異 常を認めないことがあるが, 造影 CT では上矢状洞 の血栓で血栓部の造影効果が久損するいわゆる empty delta sign ${ }^{16)}$ を呈する。造影 CT や CTVでは腎 機能障害やアレルギーに注意が必要である。MRI は CT よりも脳静脈洞血栓症の診断に優れていると される，脳実質病変では浮腫や出血の検出が可能で あり，また MRV も施行することにより静脈閉塞部 位の検出が可能となる. 脳血管撮影も診断に有用で あるが，最近では CTVや MRV の存在もあり，血 管内手術や他の検査で診断が困難な際に施行される ことが多くなっている，図 1 に自験例を示す，本例 では数日前からの頭痛があり, その後左片麻痺と痤 攣を呈したため救急搬送された。上矢状静脈洞血栓 症と診断し治療を行った。この症例ではプロテイン $S$ 遺伝子異常症を認めている ${ }^{17)}$.

\section{4. 治療と管理}

$\mathrm{AHA} / \mathrm{ASA}^{3)}$ で推奨されている脳静脈洞血栓症の 治療指針を示す (図 2). 脳静脈洞血栓症と診断した ら, 急性期は Stroke Unitでの管理が推奨される. 急性期の抗凝固療法について, 脳静脈洞血栓症では 診断時に出血性梗塞や脳内出血を生じていることが 多く, 議論がされている. 大規模研究で初期の抗凝 固療法がほぼ全例にされているが，明らかな増悪は なく支持される治療法とされている ${ }^{10)}$. 感染症の合 併には注意が必要であり, 抗生物質の投与と感染源 のドレナージを考慮すべきである。

急性期の rtPA(recombinant tissue plasminogen activa- 


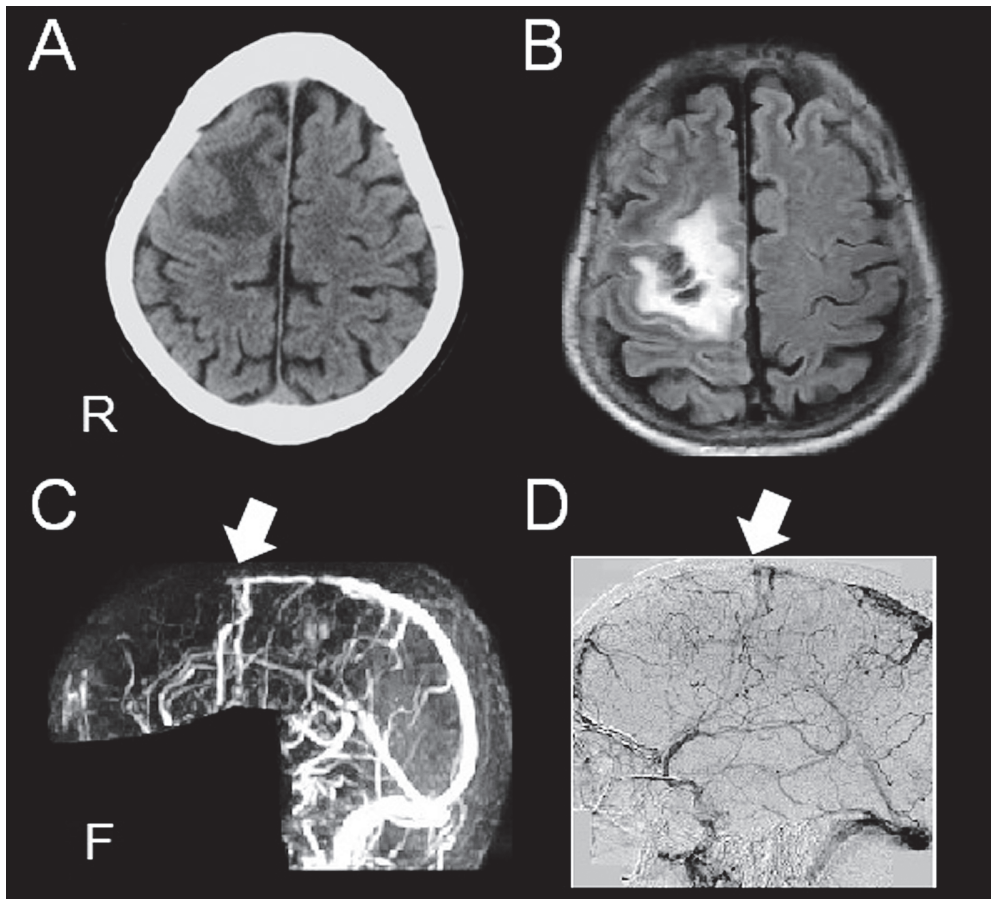

図 1 自験例の頭部画像

$\mathrm{A}$ : 頭部単純 CT, B : 頭部単純 MIRI T2 強調画像, C : MR venography, D : 脳血管撮影

頭部単純 CT では右前頭葉に低吸収域を(A)，頭部単純 MRI T2 強調画 像では同部位に高信号病変を認める $(\mathrm{B})$. MRV と脳血管撮影では上矢 状洞の閉塞を認める $(\mathrm{C}, \mathrm{D})$

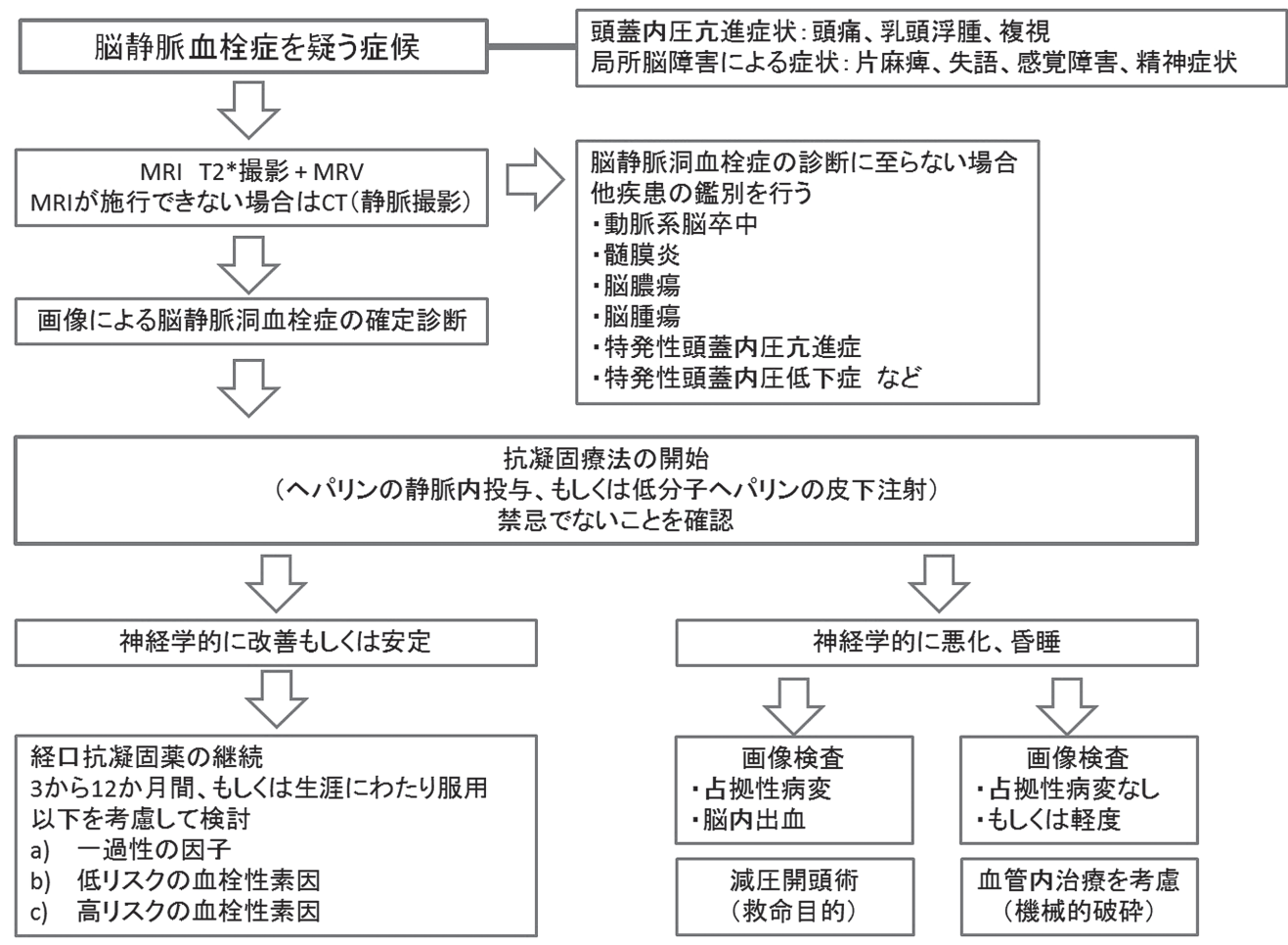

図 2 脳静脈洞血栓の管理(文献 3 より改変) 
tor) 療法, カテーテル血栓溶解術, 機械的血栓摘出術 などの血管内治療は現在のところ有用性が確立され ていないが，有用とする報告が多く認められる ${ }^{18-21)}$.

長期管理としては，遺伝性血栓性素因などを認め た場合は抗凝固療法 (INR 2.0-3.0) が推奨されている が，特定の血栓性素因が存在しない場合は 3 から 12 力月間, 経口抗凝固療法を継続する。 また痤攣 発作を呈した症例では抗痤攣薬の予防的投与が妥当 とされるが，発作のない患者への投与が有害とされ る場合もあり注意が必要である。

\section{5. おわりに}

脳静脈洞血栓症は比較的まれな疾患ではあるが, 若年者に多く発症する脳卒中として重要である。原 因は様々であり，全身疾患を伴うことがあるためこ れらのことを念頭に置き診療を行う必要がある.

\section{著者の利益相反 (COI)の開示 :}

冨本秀和：講演料 第一三共株式会社

その他著者全員の利益相反 $(\mathrm{COI})$ の開示 :

本論文発表内容に関連して開示すべき企業との利益 相反なし

\section{文献}

1) Stam J: Thrombosis of the cerebral veins and sinuses. N Engl J Med 352: 1791-1798, 2005.

2) Canhão P, Ferro JM, Lindgren AG, Bousser MG, Stam J, Barinagarrementeria F; ISCVT Investigators: Causes and predictors of death in cerebral venous thrombosis. Stroke 36: 1720-1725, 2005.

3) Saposnik G, Barinagarrementeria F, Brown RD, Bushnell CD, Cucchiara B, Cushman M, deVeber G, Ferro JM, Tsai FY; American Heart Association Stroke Council and the Council on Epidemiology and Prevention: Diagnosis and management of cerebral venous thrombosis: a statement for healthcare professionals from the American Heart Association/American Stroke Association. Stroke 42: 1158-1192, 2011.

4) Bombeli T, Basic A, Fehr J: Prevalence of hereditary thrombophilia in patients with thrombosis in different venous systems. Am J Hematol 70: 126-132, 2002.

5) Shindo $A$, Wada $H$, Ishikawa $H$, Ito $A$, Asahi M, Ii Y, Ikejiri M, Tomimoto H: Clinical features and underlying causes of cerebral venous thrombosis in Japanese patients. Int J Hematol: in press, 2014.

6) Takamiya O, Ishida F, Kodaira H, Kitano K: APC-resistance and $\mathrm{Mnl}$ I genotype (Gln 506) of coagulation factor $\mathrm{V}$ are rare in Japanese population. Thromb Haemost 74: 996, 1995.
7) Miyata T, Kimura R, Kokubo Y, Sakata T: Genetic risk factors for deep vein thrombosis among Japanese: importance of protein S K196E mutation. Int J Hematol 83: 217-223, 2006.

8) Ogata T, Kamouchi M, Kitazono T, Kuroda J, Ooboshi H, Shono T, Morioka T, Ibayashi S, Sasaki T, Iida M: Cerebral venous thrombosis associated with iron deficiency anemia. J Stroke Cerebrovasc Dis 17: 426-428, 2008.

9) Misra UK, Kalita J, Bansal V, Nair PP: Paroxysmal nocturnal haemoglobinuria presenting as cerebral venous sinus thrombosis. Transfus Med 18: 308-311, 2008.

10) Ferro JM, Canhão P, Stam J, Bousser MG, Barinagarrementeria F; ISCVT Investigators: Prognosis of cerebral vein and dural sinus thrombosis: results of the International Study on Cerebral Vein and Dural Sinus Thrombosis (ISCVT). Stroke 35: 664 670, 2004.

11) De Cruz P, Lust M, Trost N, Wall A, Gerraty R, Connell WR: Cerebral venous thrombosis associated with ulcerative colitis. Intern Med J 38: 865-867, 2008.

12) Aguiar de Sousa D, Mestre T, Ferro JM: Cerebral venous thrombosis in Behçet's disease: a systematic review. J Neurol 258: 719-727, 2011.

13）赤澤宗俊, 東條伸平, 権丈洋徳, 遠城幸子, 西田眞, 梅津隆：妊娠に伴う脳静脈洞血栓症について：自験例 を含む本邦 73 例の文献的検討. 日本周産期 - 新生児医 学会雑誌 48: 87-94, 2012.

14) Cumurciuc R, Crassard I, Sarov M, Valade D, Bousser MG: Headache as the only neurological sign of cerebral venous thrombosis: a series of 17 cases. J Neurol Neurosurg Psychiatry 76: 1084-1087, 2005.

15) Kosinski CM, Mull M, Schwarz M, Koch B, Biniek R, Schläfer J, Milkereit E, Willmes K, Schiefer J: Do normal Ddimer levels reliably exclude cerebral sinus thrombosis? Stroke 35: 2820-2825, 2004.

16) Ford K, Sarwar M: Computed tomography of dural sinus thrombosis. AJNR Am J Neuroradiol 2: 539-543, 1981.

17) Shindo A, Ikejiri M, Ii Y, Nakatani K, Wada H, Nobori T, Tomimoto $\mathrm{H}$ : A novel protein $\mathrm{S}$ gene mutation combined with protein S Tokushima mutation in a patient with superior sagittal sinus thrombosis. J Neurol 259: 178-179, 2012.

18) Mohammadian R, Sohrabi B, Mansourizadeh R, Mohammadian F, Nazempour A, Farhoudi M, Pashapour A, Taher Aghdam AA, Hashemzadeh A, Pourkakrodi M: Treatment of progressive cerebral sinuses thrombosis with local thrombolysis. Interv Neuroradiol 18:89-96, 2012.

19) Dentali F, Squizzato A, Gianni M, De Lodovici ML, Venco A, Paciaroni M, Crowther M, Ageno W: Safety of thrombolysis in cerebral venous thrombosis. A systematic review of the literature. Thromb Haemost 104: 1055-1062, 2010.

20) Pfefferkorn T, Crassard I, Linn J, Dichgans M, Boukobza M, Bousser MG: Clinical features, course and outcome in deep cerebral venous system thrombosis: an analysis of 32 cases. $\mathrm{J}$ Neurol 256: 1839-1845, 2009.

21) La Barge DV, Bishop FS, Stevens EA, Eskandari R, Schmidt RH, Skalabrin EJ, Ng PP: Intrasinus catheter-directed heparin infusion in the treatment of dural venous sinus thrombosis. AJNR Am J Neuroradiol 30: 1672-1678, 2009. 